\title{
DO HIBRIDISMO E DA DIVERSIDADE CULTURAL DECORRENTE DA INTENSIFICAÇÃO DO AFLUXO DE REFUGIADOS: PROBLEMA OU RIQUEZA \\ SOCIAL?
}

\author{
Valéria Silva Galdino Cardin* \\ Flávia Francielle da Silva**
}

\section{RESUMO}

O presente trabalho tem como escopo abordar a crise migratória vivenciada nos últimos anos pela comunidade internacional, decorrente da intensificação dos deslocamentos forçados, com foco nos choques culturais oriundos do contato entre nacionais e estrangeiros, buscando neste contexto entender se a diversidade cultural se trata de um problema ou uma riqueza social. Destaca-se que para o desenvolvimento deste estudo, optou-se por utilizar o método teórico. Palavras-chave: Direitos Humanos. Diversidade Cultural. Multiculturalismo. Refugiados. Segregação Cultural

\section{HYBRIDISM AND CULTURAL DIVERSITY ARISING OUT OF THE INTENSIFICATION OF REFUGEE AFFLUX: PROBLEM OR SOCIAL WEALTH?}

\begin{abstract}
The present work aims to address the migratory crisis experienced in recent years by the international community, due to the intensification of forced displacements, focusing on the cultural shocks arising from the contact between nationals and foreigners, seeking in this context to understand if cultural diversity is about A problem or a social wealth. It is highlighted that for the development of this study, it was chosen to use the theoretical method.
\end{abstract}

Keywords: Human rights. Cultural diversity. Multiculturalism. Refugees. Cultural Segregation.

\footnotetext{
* Pós-doutora em Direito pela Universidade de Lisboa; Doutora e mestre em Direito das Relações Sociais pela Pontifícia Universidade Católica de São Paulo; Professora da Universidade Estadual de Maringá e da Unicesumar - Centro Universitário Cesumar; Advogada no Paraná. valeria@galdino.adv.br.

** Mestranda em Ciências Jurídicas pela Unicesumar - Centro Universitário Cesumar. Especialista em Direito Contratual da Empresa pela UniCuritiba - Centro Universitário de Curitiba. Graduada em Direito pela UEPG Universidade Estadual de Ponta Grossa. Advogada no Paraná. flaviafrancielle@gmail.com.
} 


\section{INTRODUÇÃO}

O fluxo migratório e a preocupação com aqueles que migram de forma forçada não são fenômenos recentes, já em 1951, após milhares de pessoas terem sido obrigadas a deslocarem-se de forma forçada durante a Segunda Guerra Mundial, foi elaborada a Convenção relativa ao Estatuto dos Refugiados.

Apesar da referida Convenção ser considerada um marco jurídico no Direito dos Refugiados, foi o Protocolo sobre o Estatuto dos Refugiados de 1967 o responsável por trazer a necessária universalidade e amplitude ao conceito de refugiado, já que excluiu a limitação temporal (o temor de perseguição estava relacionado aos acontecimentos ocorridos antes de $1^{\circ}$ de janeiro de 1951) e geográfica (fatos ocorridos exclusivamente em território europeu), até então previstos no documento que o antecedeu.

Hodiernamente, a intensificação dos fluxos migratórios, em proporções sem precedentes históricos, tem propiciado o contato de diversos povos culturalmente díspares e, não raramente, sua coexistência em espaços comuns, fenômeno este que nem sempre se dá de forma pacífica, por vezes, impulsionando choques socioculturais e a implementação de políticas que tendem a segregar e extirpar hábitos culturais que destoam da coletividade, mesmo sendo a cultura considerada, a nível mundial, um direito essencial ao pleno desenvolvimento do ser humano.

Sendo assim, o presente trabalho - que se materializa por intermédio do método teórico - tem como objetivo analisar a atual crise migratória vivenciada pela comunidade internacional, decorrente da intensificação do afluxo de refugiados, com foco para os choques culturais oriundos do contato entre nacionais e estrangeiros, buscando neste contexto entender, frente à sua deturpação e segregação, se a diversidade cultural trata-se de um problema ou uma riqueza social e, se é passível de ser gerenciada.

\section{DA CULTURA, DA DIVERSIDADE CULTURAL E DOS DIREITOS HUMANOS}

Humanidade e cultura são termos indissociáveis, pois é por meio da forma como "os seres humanos ressentem, concebem e vivenciam o seu ambiente natural e social, ou seja, através das suas culturas, que se pode tentar compreendê-lo", sendo que o futuro é projetado e alicerçado de acordo com a cultura que se herda do passado, "enriquecida por tudo o que o 
presente lhe traz", moldando a existência e organização coletiva e individual do indivíduo (CLAVAL e STASZACK, 2008, p. 3; DIOGO, 2011, p. 92).

A cultura mostra-se dinâmica, um "conceito aberto, irreconduzível a qualquer definição imposta por instâncias ou instituições políticas ou a qualquer caracterização tipológico-formal", de modo que sua amplitude varia, principalmente, conforme o aspecto sob o qual é analisada (CANOTILHO, 2007, p. 620).

Inicialmente, ao ser sintetizada por Edward Tylor sua conotação abarcava todo o complexo metabiológico desenvolvido pelo ser humano, conceito este que passou a ser reformulado com o passar do tempo, abarcando diversos sentidos, conforme a área do conhecimento que a toma como objeto de estudo. Assim, enquanto para as Ciências Sociais a cultura corresponde ao aspecto da vida social, ligado às práticas culturais, costumeiras e folclóricas, por exemplo, para a Sociologia sintetiza tudo o que é aprendido e compartilhado dentro de um grupo social, conferindo-lhes identidade e propulsionando o sentimento de pertença social (ALMEIDA, 2008, p. 4-9).

Já sob o aspecto jurídico, pode ser considerada sob uma perspectiva mais limitativa onde a cultura é vista como "realidade intelectual e artística, correspondente ao universo das belas artes e belas letras", intermediária, que não abarca "apenas o domínio de criação e da fruição intelectual e artística, mas que procede também ao respectivo relacionamento com outros direitos espirituais" e, em uma acepção mais ampla, a cultura é definida como uma "realidade complexa, enraizada em grupos sociais, agregados populacionais ou comunidades políticas, que conjuga nomeadamente elementos de ordem histórica, filosófica, antropológica, sociológica ou mesmo psicológica", coadunando-se o presente trabalho com a abrangência desta última (SILVA, 2007, p. 9-11).

Isso porque, entende-se que a cultura, em sentido amplo, é sinônimo de humanidade, de tal modo que "cada homem ou mulher é, antes do mais, conformado pela cultura em que nasce e se desenvolve", não se restringindo à língua e a forma de expressão, concatena desde os costumes habituais da coletividade, símbolos e artefatos, crenças e religião, bem como a própria organização político-social, emergindo como fator decisivo no processo de aprendizagem, formação e inserção do ser humano frente à uma coletividade, o que dá ao tema relevância política, social e jurídica (MIRANDA, 2006, p. 02; CARDIN e SILVA, 2016).

Destaca-se que um dos seus pilares é a diversidade cultural, que é considerada patrimônio comum da humanidade e um atributo essencial capaz de criar "um mundo rico e 
variado que aumenta a gama de possibilidades e nutre as capacidades e valores humanos", e que por tal motivo demanda proteção a nível internacional (CHIRIBOGA, 2006; ONU, 2005).

Neste contexto, forçoso reconhecer que a cultura desponta como um direito humano, já que emerge como parte essencial do desenvolvimento humano, já que quando salvaguardado o seu exercício de forma livre possibilita que possa essa pessoa escolher "sua identidade - quem ela é - sem perder o respeito dos outros, ou ser excluída de outras opções", por isso importante para uma vida digna e plena, tanto é verdade que a própria Declaração Universal em 1948 elencou a cultura como um direito, conforme se extrai de seu artigo $27^{1}$, onde consta genericamente que toda pessoa tem o "direito a tomar parte livremente da vida cultural da comunidade". (ONU, 2004; PIOVESAN, 2003; ONU, 1948).

De um modo geral, a aprovação da Declaração de 1948 não só desponta como um marco na concepção contemporânea de direitos humanos, como é a partir dela que:

[...] começa a se desenvolver o Direito internacional dos Direitos Humanos, mediante a adoção de inúmeros tratados internacionais voltados à proteção de direitos fundamentais. Os instrumentos internacionais de proteção refletem, sobretudo, a consciência ética contemporânea compartilhada pelos Estados, na medida em que invocam o consenso internacional acerca de temas centrais aos direitos humanos. (PIOVESAN, 2003, p. 39).

Sequencialmente, foram diversas declarações e convenções que buscaram salvaguardar direitos culturais, como por exemplo a Declaração da Cidade do México sobre Políticas Culturais de 1982, que trouxe em seu bojo a conceitualização do termo "cultura"2 e, a nova Declaração do México de 1985, que trouxe ao âmbito internacional expressivas acepções e diretrizes sobre identidade cultural $^{3}$, realçando a relação entre a cultura, direito à identidade e direitos sociais (ONU, 1982; ONU, 1985; CARDIN e SILVA, 2016).

Em 1992, foi aprovada a Declaração Sobre os Direitos das Pessoas Pertencentes a Minorias Nacionais ou Étnicas, Religiosas e Linguísticas, que reasseverou o compromisso dos Estados em proteger “a existência e a identidade nacional ou étnica, cultural, religiosa e

\footnotetext{
${ }^{1}$ Artigo $27^{\circ}: 1$. Toda a pessoa tem o direito de tomar parte livremente na vida cultural da comunidade, de fruir as artes e de participar no progresso científico e nos benefícios que deste resultam; 2.Todos têm direito à proteção dos interesses morais e materiais ligados a qualquer produção científica, literária ou artística da sua autoria.

${ }^{2}$ Segundo a mencionada Declaração, cultura compreende o "conjunto dos traços distintivos, espirituais e materiais, intelectuais e afetivos que caracterizam uma sociedade ou um grupo social e que abarca, para além das artes e das letras, os modos de vida, os direitos fundamentais do ser humano, os sistemas de valores, as tradições e as crenças" (ONU, 1982).

${ }^{3}$ De acordo com a Declaração do México (1985) a identidade cultural "é uma riqueza que dinamiza as possibilidades de realização da espécie humana ao mobilizar cada povo e cada grupo a nutrir-se de seu passado e a colher as contribuições externas compatíveis com a sua especificidade e continuar, assim, o processo de sua própria criação" (ONU, 1985).
} 
linguística das minorias dentro de seus respectivos territórios e fomentarão condições para a promoção de identidade", de acordo com seu artigo $1^{04}$, entretanto, não de forma absoluta, já que segundo o seu artigo $4^{\circ}$, item $2^{5}$, o direito de desenvolver a sua cultura e tradições desde que em consonância com a legislação nacional e, não contrárias às normas internacionais.

Merece ainda destaque, a Convenção para Salvaguarda do Patrimônio Imaterial, aprovada em Paris no ano de 2003, cujo objetivo é proteger o patrimônio cultural imaterial, tida como principal "fonte de diversidade cultural", bem como "garantia de desenvolvimento sustentável", conforme preconizado em seu preâmbulo, bem como a Convenção sobre Proteção e Promoção da Diversidade das Expressões Culturais, que além de conceituar o termo diversidade cultural $^{6}$, elencou em seu artigo $2^{\circ 7}$ oito princípios fundamentais

\footnotetext{
4 “Artigo $1 .^{\circ}:$ 1. Os Estados deverão proteger a existência e a identidade nacional ou étnica, cultural, religiosa e linguística das minorias no âmbito dos seus respectivos territórios e deverão fomentar a criação das condições necessárias à promoção dessa identidade; 2. Os Estados deverão adoptar medidas adequadas, legislativas ou de outro tipo, para atingir estes objetivos".

${ }^{5}$ Artigo 4. ${ }^{\circ}[\ldots]$ 2. Os Estados deverão adoptar medidas a fim de criar condições favoráveis que permitam às pessoas pertencentes a minorias manifestar as suas características e desenvolver a sua cultura, língua, religião, tradições e costumes, a menos que determinadas práticas concretas violem a legislação nacional e sejam contrárias às normas internacionais.

${ }^{6}$ Artigo 4 - Definições: Para os fins da presente Convenção, fica entendido que: "Diversidade cultural" refere-se à multiplicidade de formas pelas quais as culturas dos grupos e sociedades encontram sua expressão. Tais expressões são transmitidas entre e dentro dos grupos e sociedades.A diversidade cultural se manifesta não apenas nas variadas formas pelas quais se expressa, se enriquece e se transmite o patrimônio cultural da humanidade mediante a variedade das expressões culturais, mas também através dos diversos modos de criação, produção, difusão, distribuição e fruição das expressões culturais, quaisquer que sejam os meios e tecnologias empregados [...].

${ }^{7}$ Artigo 2 - Princípios Diretores: 1 . Princípio do respeito aos direitos humanos e às liberdades fundamentais - A diversidade cultural somente poderá ser protegida e promovida se estiverem garantidos os direitos humanos e as liberdades fundamentais, tais como a liberdade de expressão, informação e comunicação, bem como a possibilidade dos indivíduos de escolherem expressões culturais. Ninguém poderá invocar as disposições da presente Convenção para atentar contra os direitos do homem e as liberdades fundamentais consagrados na Declaração Universal dos Direitos Humanos e garantidos pelo direito internacional, ou para limitar o âmbito de sua aplicação; 2. Princípio da soberania - De acordo com a Carta das Nações Unidas e com os princípios do direito internacional, os Estados têm o direito soberano de adotar medidas e políticas para a proteção e promoção da diversidade das expressões culturais em seus respectivos territórios; 3. Princípio da igual dignidade e do respeito por todas as culturas - A proteção e a promoção da diversidade das expressões culturais pressupõem o reconhecimento da igual dignidade e o respeito por todas as culturas, incluindo as das pessoas pertencentes a minorias e as dos povos indígenas; 4. Princípio da solidariedade e cooperação internacionais - A cooperação e a solidariedade internacionais devem permitir a todos os países, em particular os países em desenvolvimento, criarem e fortalecerem os meios necessários a sua expressão cultural - incluindo as indústrias culturais, sejam elas nascentes ou estabelecidas - nos planos local, nacional e internacional; 5. Princípio da complementaridade dos aspectos econômicos e culturais do desenvolvimento - Sendo a cultura um dos motores fundamentais do desenvolvimento, os aspectos culturais deste são tão importantes quanto os seus aspectos econômicos, e os indivíduos e povos têm o direito fundamental de dele participarem e se beneficiarem; 6. Princípio do desenvolvimento sustentável - A diversidade cultural constitui grande riqueza para os indivíduos e as sociedades. A proteção, promoção e manutenção da diversidade cultural é condição essencial para o desenvolvimento sustentável em benefício das gerações atuais e futuras; 7. Princípio do acesso equitativo - $\mathrm{O}$ acesso eqüitativo a uma rica e diversificada gama de expressões culturais provenientes de todo o mundo e o acesso das culturas aos meios de expressão e de difusão constituem importantes elementos para a valorização da diversidade cultural e o incentivo ao entendimento mútuo; 8 . Princípio da abertura e do equilíbrio - Ao adotarem medidas para favorecer a diversidade das expressões culturais, os Estados buscarão
} 
relacionados aos aspectos culturais como, por exemplo, o respeito aos direitos humanos, o princípio do respeito igualitário de todas as culturas, o princípio da solidariedade, o princípio da cooperação internacional e o princípio do desenvolvimento sustentável, balizadores para a atuação internacional.

\section{DOS DESLOCAMENTOS FORÇADOS: CONTEXTUALIZAÇÃO DA CRISE MIGRATÓRIA CONTEMPORÂNEA}

O fluxo migratório e a preocupação com os refugiados ${ }^{8}$ não são fenômenos recentes, isso porque "por razões políticas, religiosas, sociais, culturais ou de gênero, milhões de pessoas já tiveram que deixar seus países e buscar proteção internacional em outros”. Como ocorreu na Segunda Guerra Mundial, por exemplo, que levou milhares de pessoas, de forma forçada, a se deslocarem pelo mundo, que por conseguinte impulsionou a criação do Alto Comissariado das Nações Unidas para Refugiados no ano de 1950, organismo responsável por coordenar a atuação internacional para resguardar as pessoas deslocadas (BARRETO, 2010; PAMPLONA e PIOVESAN, 2015).

A respeito deste período, pontua Jacob Dolinger que foi:

[...] o sofrimento inenarrável vivenciado por milhões de criaturas humanas que sobreviveram à grande catástrofe do século XX, a Segunda Guerra Mundial (que ceifou a vida de mais de quarenta milhões de pessoas), levou as Nações Unidas a elaborar uma das mais importantes convenções internacionais, que regula a situação jurídica dos refugiados (DOLINGER, 2008, p. 242).

Assim, em 1951 foi elaborada a Convenção relativa ao Estatuto dos Refugiados, que veio aclarar a condição jurídica do refugiado, definindo-o como toda pessoa que "em consequência dos acontecimentos ocorridos antes de $1^{\circ}$ de janeiro de 1951 , e temendo ser perseguida [...] se encontre fora do seu país de nacionalidade [...]" (ONU, 1951).

A referida acepção mostrou-se claramente restritiva, ao preconizar que o alegado receio de perseguição deveria estar atrelado aos acontecimentos ocorridos antes de $1^{\circ}$ de janeiro de 1951, bem como deixou aos estados contratantes a liberdade para definirem "a restrição geográfica dos acontecimentos que fundamentariam o pedido de refúgio,

promover, de modo apropriado, a abertura a outras culturas do mundo e garantir que tais medidas estejam em conformidade com os objetivos perseguidos pela presente Convenção.

${ }^{8}$ Quanto a preocupação com refugiados, há registros desde o ano de 1921, por conta da queda do Império Otomano e da Revolução Russa, quanto à proteção de pessoas que se encontram em situações especiais de abandono e desamparo no país ao qual pertencem. (PAMPLONA e PIOVESAN, 2015). 
estabelecendo que os fatos deveriam ter ocorrido na Europa" (PAMPLONA e PIOVESAN, 2015).

Considerando que as transformações sociais já não se coadunavam com as restrições temporais e geográficas, emergiu a necessidade da ampliação do conceito de refugiado, desta forma abriu-se, em 1967, para adesão o Protocolo sobre o Estatuto dos Refugiados, que colocou fim à limitação temporal e geográfica, conforme previsto no artigo $1^{9}$ do referido protocolo (ONU, 2013).

Em que pese a relevância social e jurídica dos referidos Diplomas Legais no âmbito internacional, fato é que "com o passar dos anos, muitos poucos refugiados se enquadravam na definição "clássica" de refugiado", em especial, aqueles que eram obrigados a deslocaremse em razão de conflitos no continente africano e americano (PAMPLONA e PIOVESAN, 2015; PACÍFICO, 2008).

De tal modo, documentos de amplitude regional passaram a serem firmados, no intuito de atender as especificidades em cada bloco territorial, sendo que em 1969 foi assinada a Convenção da Organização da Unidade Africana (OUA) ${ }^{10}$, já em 1984 foi assinada no continente americano a Declaração de Cartagena $^{11}$, que ampliaram as situações e circunstâncias capazes de ensejar o enquadramento na categoria de refugiado, passando a partir de então a ser a violação maciça dos direitos humanos o núcleo vital para a concessão do refúgio (OUA, 1969; OEA, 1984).

Aliás, circunstâncias estas que podem ser observadas em grande quantidade a nível mundial, já que desde o ano de 2012 o afluxo de pessoas em busca de refúgio foi aos poucos intensificando-se, chegando ao seu ápice no ano de 2015, com um total de 65,3 milhões de

\footnotetext{
${ }^{9}$ ARTIGO1 - Disposiç̃os Gerais: §1. Os Estados Membros no presente Protocolo comprometer-se-ão a aplicar os artigos 2 a 34, inclusive, da Convenção aos refugiados, definidos a seguir; §2. Para os fins do presente Protocolo, o termo "refugiado", salvo no que diz respeito à aplicação do $§ 3$ do presente artigo, significa qualquer pessoa que se enquadre na definição dada no artigo primeiro da Convenção, como se as palavras "em decorrência dos acontecimentos ocorridos antes de $1^{\circ}$ de janeiro de 1951 e..." e as palavras "...como consequiência de tais acontecimentos" não figurassem do §2 da seção A do artigo primeiro.

O presente Protocolo será aplicado pelos Estados Membros sem nenhuma limitação geográfica; entretanto, as declarações já feitas em virtude da alínea "a" do §1 da seção B do artigo1 da Convenção aplicar-se-ão, também, no regime do presente Protocolo, a menos que as obrigações do Estado declarante tenham sido ampliadas de conformidade com o §2 da seção B do artigo 1 da Convenção (ONU, 2013).

${ }^{10}$ No item 2 do artigo $1^{\circ}$ da referida Convenção, estabeleceu-se que também seria aplicado o termo refugiado para aqueles "que, devido a uma agressão, ocupação externa, dominação estrangeira ou a acontecimentos que perturbem gravemente a ordem pública numa parte ou na totalidade do seu país de origem ou do país de que tem nacionalidade, seja obrigada a deixar o lugar da residência habitual para procurar refúgio noutro lugar fora do seu país de origem ou de nacionalidade" (OUA, 1969).

${ }^{11}$ Nos termos do item III da referida Declaração, na Terceira conclusão, considera-se refugiado aqueles que "tenham fugido dos seus países porque a sua vida, segurança ou liberdade tenham sido ameaçadas pela violência generalizada, a agressão estrangeira, os conflitos internos, a violação maciça dos direitos humanos ou outras circunstâncias que tenham perturbado gravemente a ordem pública", (OEA, 1984).
} 
pessoas deslocadas pelo mundo, principalmente, em razão de guerras e conflitos armados, sendo que deste número os novos deslocados, apenas no ano de 2015, somaram cerca de 12,4 milhões, o que significa que a uma em cada cento e treze pessoas no mundo era então solicitante de refúgio (ACNUR, 2015).

Destaca-se que novo recorde foi batido também no de 2016, conforme aponta o atual Relatório Tendencias Globales ${ }^{12}$ (Tendências Globais - tradução livre do espanhol), período em que o número de deslocamentos forçados chegaram ao patamar de 65,6 milhões de pessoas $^{13}$, sendo que deste número 22,5 milhões eram refugiados, 40,3 milhões deslocados internos e 2,8 milhões requerentes de asilo, o que em escalas proporcionais significa que a cada minuto do ano de 2016 cerca de 20 (vinte) pessoas foram obrigadas a deixar seu país de residência habitual (ACNUR, 2016).

Esse afluxo de deslocamentos forçados dá-se, principalmente, em razão das violências generalizadas de toda ordem, perseguições e dos conflitos armados, como é o caso da guerra na Síria, no Iraque, Iêmen, bem como na África Subsaariana ${ }^{14}$, no Afeganistão, na Líbia e na Ucrânia, regiões onde também concentram-se os países mais afetados pelos deslocamentos forçados no último ano, quais sejam: Síria em primeiro lugar (12 milhões de pessoas), seguido do Afeganistão (4,7 milhões de pessoas), Iraque (4,2 milhões de pessoas), Sudão do Sul (3,3 milhões de pessoas) e Sudão (2,9 milhões de pessoas) (ACNUR, 2016).

Contudo, insta salientar, que apesar do foco midiático ser o fluxo de refugiados decorrentes do Oriente Médio, como da África rumo aos países europeus, a problemática afeta também regiões ocidentais, como é o caso da América Central, especificamente, na região do Triângulo do Norte da América Central (NTCA) - composta por El Salvador, Guatemala e Honduras, considerada um dos lugares mais violentos do mundo por conta do domínio de grupos criminosos armados e organizados, que no último ano fez com que cerca de 388.000 (trezentas e oitenta e oito mil) pessoas deixassem a região, tendo os Estados Unidos, o México, Belize, a Costa Rica, o Nicarágua e o Panamá como destinos (ACNUR, 2014; ACNUR, 2015).

\footnotetext{
12 O relatório "Tendências Globais" é elaborado anualmente pelo Alto Comissariado das Nações Unidas para Refugiados (ACNUR), sendo que o mais recente é o do ano de 2016.

${ }^{13}$ A dimensão contemporânea dos fluxos migratórios fica mais evidente ao comparar o aumento progressivo do numero de pessoas em deslocamento nas últimas duas décadas, cujo total passou de 33.9 milhões em 1997 para os ditos 65.6 milhões em 2016.

${ }^{14}$ Conflitos regionais assolam Burundi, República Central Africana, República Democrática do Congo, Sudão do Sul e Sudão.
} 
O processo de integração também é falho, isso porque as soluções (quando) buscadas visam primeiramente, ou tão somente, a integração econômica daqueles que buscam refúgio, ao passo que, por vezes, até conscientemente:

[...] outras formas de se integrar o indivíduo na comunidade receptora podem ser negligenciadas, o que afeta de modo decisivo a realização plena da integração local. Uma das dimensões que pode vir a ser deixada em segundo plano é a cultural, a qual será mostrada neste artigo como fundamental para a concretização dos outros componentes desta solução duradoura. Além disso, será defendido aqui que somente após conseguir se adaptar culturalmente à nova comunidade - ajustando-se a cultural local, sem necessitar abandonar a sua própria - é que o indivíduo em refúgio estará completamente integrado (FONSECA et. al., 2011, p. 13).

Possível inferir que, frente as estatísticas apresentadas e atuais conjunturas vivenciadas pela comunidade internacional, tais como guerras e conflitos armados que se estendem à anos, não há indicativos de tréguas quanto o afluxo de pessoas circulando pelo mundo seja para proteger sua vida, ou ainda na busca por melhores condições de vida.

\section{DOS CHOQUES SOCIOCULTURAis: A DIFERENÇA CULTURAL COMO FATOR DE SEGREGAÇÃO DOS REFUGIADOS}

Como visto a intensificação o fluxo de pessoas, em especial, aquelas que são obrigadas a buscarem refúgio em outros países é uma realidade inevitável, que tem propiciado a criação de um mosaico de línguas e culturas em um mesmo espaço geográfico, não raramente, provocando tensões e conflitos socioculturais, já que impera "o medo de uma invasão migratória, os riscos de desemprego para os trabalhadores autóctones, a perda da identidade nacional e, até, o espetro do terrorismo" (MARINUCCI e MILESI, 2011, p. 10).

Neste contexto, não é difícil imaginar que o refugiado além dos percalços enfrentados no decorrer da viagem, sujeitando-se aos infortúnios das próprias rotas de migração clandestinas, bem como abusos de contrabandistas e traficantes, quando (e se) consegue ingressar no país receptor passa então a encontrar dificuldades para se integrar à comunidade nativa, sendo marginalizados e excluídos de plano.

Frise-se que desavenças motivadas pela diferença é fato social que sempre acompanhou a história da humanidade, em razão da "ideia de grupo e, amiúde, pelo não reconhecimento de outros, como um de seus pares", sendo que os estrangeiros de um modo geral, refugiados, migrantes internacionais, apátridas, entre outros, "foram passados, 
inicialmente, pelo fio das lanças e espadas dos soldados, para, em algum momento, tornaremse prisioneiros convertidos em escravos" (FONTES, 2014, p. 53).

Essas intolerâncias e segregações, conforme pontua Flávia Piovesan, "tiveram como fundamento a dicotomia do "eu" versus o "outro", em que a diversidade era captada como elemento para aniquilar direitos", isso é ser diferente visibilizava "conceber o "outro" como um ser menor em dignidade e direitos", até mesmo descartável, como ocorreu nos tempos da escravidão, do nazismo, da homofobia, da xenofobia, entre outras práticas no mesmo sentido (PIOVESAN, 2009, p. 295-296).

Tais assertivas tornam a situação hoje vigente cada vez mais preocupante, isso porque, em termos práticos constata-se que os refugiados não dispõem de "um lugar no mundo onde possam existir dignamente", já que não são vistos como sujeito de direitos, mas sim como um problema político-social, e por tal motivo "não possuem um status político que lhes possibilite ser tratados pelos demais como semelhantes" (WINCKLER, 2001, p. 121).

Sendo que, socialmente, os refugiados, enquanto grupo social, padece coletivamente frente à juízos de valores e pré-julgamentos, ainda que sejam estes motivados pelo comportamento de uma minoria, na verdade culturalmente:

[...] o comportamento desviante estigmatiza o grupo, conscientizando-o da possibilidade constante de ser alvo da repressão. Forma-se uma visão do mundo que passa a circular, não monoliticamente, entre seus membros. $O$ que se pode depreender dos trabalhos realizados por pesquisadores é a presença de uma frustração em fase de toda conjuntura sociocultural e política. Considerando a natureza da cultura, essa manifestação subcultural envolve campo de interação com caráter, próprio, compreendendo também símbolos e valores comuns. (CASTRO, 1999, p. 304)

Por essa perspectiva, talvez seja possível compreender (mas não aceitar) os episódios de xenofobia e ódio imotivados, por parte de integrantes das comunidades receptoras, direcionados aos refugiados, como a lamentável atitude da cinegrafista húngara Petra Lászlö, que no final de 2015 foi flagrada chutando sírios na fronteira com a Sérvia, ou ainda no recente episódio em que um refugiado sírio (residente no Brasil há três anos) foi agredido verbalmente em Copacabana, por um brasileiro, enquanto trabalha vendendo comidas típicas (EL PAÍS, 2015; CARTA CAPITAL, 2017).

Em ambos os casos é possível observar que as agressões e intimidações são gratuitas e destinadas às vítimas pelo simples fato de integrarem uma dada categoria, neste caso a de refugiados estrangeiros, fruto em parte da deturpação da imagem desses indivíduos, seja pela 
mídia ou pelos discursos políticos mais conservadores, que tendem a associá-lo à ideia de clandestinidade, inferioridade e miséria, colocando-o como uma ameaça em potencial.

Fato que também impulsiona a implementação de políticas migratórias com o objetivo de impedir que os refugiados consigam transpor as fronteiras. Assim, as violações aos direitos humanos têm se propagado também nos países receptores, como é o caso da Austrália que possui uma política intransigente a respeito do tema, utilizando-se de medidas temerárias como a devolução dos barcos ao mar (refoulement) e a detenção obrigatória, por tempo indeterminado, em centros de processamento fora do continente, como Papua-Nova Guiné e Nauru (ANISTIA INTERNACIONAL, 2016).

Situação semelhante se observa também no Estados Unidos, que apesar da crise avassaladora que afeta os países da América Central, continuaram a efetuar as deportações no mesmo nível, sendo que parte desses indivíduos foram forçadas a retornar para as situações em que corriam risco de vida e, das quais estavam fugindo (ANISTIA INTERNACIONAL, 2017).

Na Ásia também merece destaque a atuação do serviço de imigração da Coreia do Sul, que deteve de forma injustificada mais de 100 (cem) pessoas solicitantes de refúgio no Aeroporto Internacional de Incheon e, a postura do Japão, que caracteristicamente costuma rejeitar a maior parte das solicitações de refúgio, resistente e omissiva frente a crise vivenciada (ANISTIA INTERNACIONAL, 2017).

Isso acontece porque, conforme coloca Cristiane Maria Sbalquiero Lopes, "os discursos da política e as práticas atuais (legislação, policialização) induzem a pensar que imigrar é crime", o que justifica o fato de que "a imigração é controlada pela polícia, e os imigrantes estão sujeitos a serem presos (ou confinados em centros de detenção, que é quase a mesma coisa) e deportados para seus países de origem”, práticas que se estendem aos refugiados (LOPES, 2009, p. 64).

O refugiado, nesta perspectiva, não apenas enquadra-se no conceito de "ser redundante" descrito por Zygmunt Bauman, como "ser extranumerário, desnecessário, sem uso - quaisquer que sejam os usos e necessidades responsáveis pelo estabelecimento dos padrões de utilidade e de indispensabilidade". Sua vida, tal como a do homo saucer, é desprovida de valor, inútil socialmente e politicamente, já que sequer a lei lhe confere proteção ante ao seu não pertencimento, sua não condição de cidadão (BAUMAN, 2005, p. 20-45). 
Situação esta, que se confirma a partir das contribuições de cada país para o acolhimento e minimização dos reflexos que assola a comunidade internacional, já que embora os pedidos de asilo sejam majoritariamente destinados aos países mais desenvolvidos e industrializados, estes são os que menos contribuem, pois aproximadamente $84 \%$ dos refugiados sob o mandato do Alto Comissariado das Nações Unidas para os Refugiados (ACNUR) encontram-se em regiões em desenvolvimento ${ }^{15}$, elucidando a falta de consenso no que diz respeito à responsabilidade dos países quanto ao acolhimento de refugiados, que ao longo dos últimos anos tem fechado suas fronteiras e limitado a entrada desses indivíduos, condenando por omissão milhares de pessoas sumariamente à morte (ACNUR, 2016).

Nesta perspectiva, notável a incongruência entre o que tem sido consolidado nas diversas declarações e convenções e a realidade em si, sendo que, contemporaneamente, os refugiados têm sido condenados diuturnamente à situações sub-humanas e periclitantes motivada principalmente pela diferença cultural, que é mola propulsora para os ditos choques socioculturais, eivados de preconceito e ódio, que desaguam ora na exclusão cultural e social, ora nas políticas xenofóbicas.

\section{DO MULTICULTURALISMO EMANCIPATÓRIO: A DIVERSIDADE CULTURAL PODE SER GERENCIADA?}

Se por um lado, a intensificação dos fluxos migratórios tem inevitavelmente levado grupos etnicamente diversos a conviverem em um mesmo espaço, por outro a insustentabilidade das atuais práticas reclamam por mudanças nas próprias políticas migratórias, pois se mostram essencialmente xenofóbicas e tem como escopo a contenção dos refugiados.

Aliás, "o medo e desconhecimento com relação ao diferente, que se reflete em xenofobia por parte dos nacionais, pode prejudicar de modo decisivo a integração cultural de pessoas em situação de refúgio, que acabam não se sentindo parte da nova comunidade”, o que impreterivelmente coloca o refugiado, parte mais vulnerável e hipossuficiente, em situação periclitante (FONSECA, 2011, p.33).

\footnotetext{
${ }^{15}$ Entre os países que mais acolheram refugiados, tem-se a seguinte ordem: Turquia (cerca de 2,9 milhões de pessoas), seguido pelo Paquistão (1,4 milhões), Líbano (1 milhão), Irã (979.400), Uganda (940.800), Etiópia (791.600), Jordânia (685.200), Alemanha (669.500), República Democrática do Congo (452.000) e Quênia (451.100) (ACNUR, 2016).
} 
Já que os reflexos da rejeição generalizada tende a impactar em todas as etapas do processo integração no país receptor, desde jurídica, econômica e social, o que escancara o fato de que a implementação de estratégias para gerenciar a diversidade cultural é medida de urgência para garantir aos mais vulneráveis condições e mecanismos para integrar-se e viver dignamente, ao passo que o multiculturalismo emerge como um possível meio de pacificação social.

Neste contexto é, importante frisar que o termo "multicultural" não se confunde com o termo "multiculturalismo", já que como pontua Hall:

[...] multicultural é um termo qualificativo. Descreve as características sociais e os problemas de governabilidade apresentados por qualquer sociedade na qual diferentes comunidades culturais convivem e tentam construir uma vida em comum, ao mesmo tempo em que retêm algo de sua identidade "original". Em contrapartida, o termo "multiculturalismo" é substantivo. Refere-se às estratégias e políticas adotadas para governar ou administrar problemas de diversidade e multiplicidade gerados pelas sociedades multiculturais (HALL, 2003, p. 52).

O multiculturalismo, por sua vez, subdivide-se em conservador e emancipatório. Sendo que no primeiro caso, reconhece-se a diferença com o objetivo de sequencialmente excluí-la, isso é busca a sua homogeneização por assimilação, isso é busca-se construir "uma cultura comum, unitária e nacional, entendendo a diversidade cultural, rácica ou sexual como devendo ser assimilada à cultura tradicional, geralmente definida por padrões patriarcais, brancos, euro americanos" (OLIVEIRA e SOUZA, 2016, p. 125).

Já o multiculturalismo emancipatório, além de se voltar à coexistência pacifica entre grupos culturalmente díspares, não busca a assimilação, mas sim o "reconhecimento da diferença e do direito à diferença e da coexistência ou construção de uma vida em comum além de diferenças de vários tipos", esvaziando desta forma a citada dicotomia do "eu versus o outro" e, contribuindo para "o surgimento de formas mais humanas de convivência e de crescimento pessoal de cada um dos seres humanos" (SANTOS e NUNES, 2010, p. 33; PIOVESAN, 2013; SOUZA, 2001).

É nesta segunda acepção que se entende que o multiculturalismo é capaz de gerir a diversidade cultural, até gradativamente se atingir a tão almejada convivência pacífica, por meio da adoção de "espaços e processos de interação positiva entre as diferentes culturas", com o escopo de gerar relações de confiança, de reconhecimento mútuo, de comunicação e diálogo, além de cooperação, sem que para isso abdique-se da diversidade existente dentro da própria cultura (LOPES, 2012, p. 70). 
Em termos práticos, considerando que boa parte da aversão aos refugiados é fruto da deturpação da imagem desses indivíduos, bem como do hibridismo e diversidade cultural provocando choques culturais no país receptor, entende-se a necessidade da desconstrução de tais preconceitos, em especial, por parte da população nativa que em regra tende a resistir, de modo que "diversidade étnica, racismo, multiculturalismo são temas que devem ser tratados de forma conjunta como efeito da distinção entre a população receptora e a população imigrante" (PATARRA, 2012).

Por outro lado, no campo das políticas públicas, destaca-se também a imprescindibilidade de que seja concedido ao refugiado meios plausíveis para reconstruir sua vida no país receptor, pois sem amparo estatal não há como se garantir a efetivação de direitos, fazendo-se mister uma mudança de perspectiva na atuação estatal a fim de integrar os refugiados, diferentemente do que tem ocorrido atualmente, como bem pontua Danielle Anne Pamplona e Flávia Piovesan:

[...] no campo dos direitos humanos, três são as clássicas obrigações do Estado: respeitar, proteger e implementar. Quanto à obrigação de respeitar, obsta ao Estado que viole tais direitos. No que tange à obrigação de proteger, cabe ao Estado evitar e impedir que terceiros (atores não-estatais) violem estes direitos. Finalmente, a obrigação de implementar demanda do Estado a adoção de medidas voltadas à realização destes direitos. Aos direitos dos refugiados corresponde os deveres e obrigações jurídicas do Estado de respeito, proteção e implementação destes direitos. Fundamental é avançar na identificação do alcance da responsabilidade dos Estados no que se refere aos direitos humanos dos refugiados (PAMPLONA e PIOVESAN, 2015).

Neste sentido, denota-se o longo caminho a ser percorrido, pois uma integração completa vai além da simples aceitação em receber o refugiado, na verdade suas ações devem ter como referencial "a busca pela condição humana plena”, possibilitando o exercício dos direitos individuais, sociais, políticos e culturais, bem como sua inclusão social, por meio do respeito as diferenças, salvaguardando-se o seu pleno desenvolvimento, passos essenciais para a construção de uma comunidade internacional harmônica e fulcrada na diferença (MELO, 2016). 


\section{CONCLUSÃO}

Do presente estudo, pode-se inferir que o aumento sem precedentes dos fluxos migratórios trouxe a tona o abismo entre as prerrogativas constantes nos instrumentos jurídicos internacionais e, as políticas migratórias adotadas pelos países de um modo geral, que visam a contenção e obstar que os refugiados se integrem à comunidade nativa, negandolhe seu modo de vida e/ou impedindo sua participação social.

Se de um lado preconiza-se os direitos humanos, a cooperação e a solidariedade no âmbito internacional para o acolhimento do refugiado, por outro, os países mostram-se extremamente fechados, negando-lhes o acesso aos direitos essenciais para uma vida minimamente digna ou omitindo-se perante as violações e posturas arbitrárias adotadas pelos demais, já que tanto socialmente, como politicamente o refugiado é não mais que mero refugo humano, cuja vida não tem qualquer valor ou relevância, podendo neste contexto ser sacrificado.

Imperioso concluir, que ainda que seja a cultura considerada, a nível mundial, um direito essencial ao pleno desenvolvimento do ser humano, cuja riqueza social é pontuada pelos mais diversos documentos, convenções e declarações, na prática a diversidade cultural e a diferença são quando muito reduzidas à mero problema social ser extirpado, assimilado ou segregado, e o refugiado taxado como indigno de desfrutar dos mesmos direitos ou participar socialmente, sendo inúmeros os episódios de truculência, preconceito e xenofobia imotivados ou movidos por pretextos torpes.

E, considerando que a solidariedade e a cooperação são princípios preconizados pela comunidade internacional, denota-se que a sociedade multicultural é uma meta a ser alcançada, sendo o multiculturalismo emancipatório peça chave nessa guinada social e cultural, tangível por meio da conscientização e desconstrução dos preconceitos que rodeiam a própria migração em si e, a implementação de políticas públicas voltadas à valorização do diferente, medidas essenciais para que tenham os refugiados condição jurídica semelhante à população nativa com direitos e garantias, independentemente das diferenças étnicas, culturais e sociais. 


\section{REFERÊNCIAS BIBLIOGRÁFICAS}

ALMEIDA, Antonio. Alguns conceitos sobre cultura. Rio de Janeiro: Clube de Autores, 2012.

ALTO COMISSARIADO DAS NAÇÕES UNIDAS PARA REFUGIADOS (ACNUR). Childrens on the run. Disponível em: <http://www.unhcr.org/about-us/background/56fc2 66f4/children-on-the-run-full-report.html>. Acesso em: 01 jun 2017.

Infográfico: Crianças em Fuga, a solução do problema. Disponível em: <http://www.acnur.org/portugues/quem-ajudamos/criancas/criancas-em-fuga/>. Acesso em: 01 jul. 2017.

- Global Trends: forced displacement in 2015. Disponível em: <https://s3.amazonaws.com/unhcrsharedmedia/2016/2016-06-20-global-trends/2016-06-14Global-Trends-2015.pdf > . Acesso em: 18 mar 2017.

Tendencias Globales: desplazamiento forzado en 2016. Disponível em: <http://s3.amazonaws.com/unhcrsharedmedia/2017/2017-06-19-Global-Trends-2016/2016_T endenciasGlobales-ESP-BAJA.pdf>. Acesso em: 24 jun. 2017.

- Women on the run. Disponível em: <http://www.unhcr.org/publications/operations/5630f24c6/women-run.html>. Acesso em: 01 jun 2017.

ANISTIA INTERNACIONAL. Informe 2015/16: o Estado dos Direitos Humanos no mundo. Disponível em: <https://anistia.org.br/wp-content/uploads/2016/02/Informe2016_Final_Web1.pdf>. Acesso em: 05 abr. 2017.

Informe 2016/17: o Estado dos Direitos Humanos no mundo. Disponível em: < https://anistia.org.br/wp-content/uploads/2017/02/AIR2017_ONLINE-v.3.pdf>. Acesso em: 05 abr. 2017

BARRETO, Luiz Paulo Teles Ferreira. A Lei Brasileira de Refúgio - sua história. BARRETO, Luiz Paulo Teles Ferreira (org.). Refúgio no Brasil: a proteção brasileira aos refugiados e seu impacto nas Américas. 1 ed. Brasília: ACNUR, Ministério da Justiça, 2010.

BAUMAN, Zygmunt. Vidas desperdiçadas. Rio de Janeiro: Jorge Zahar, 2005.

BURKE, Peter. O que é história cultural? Tradução Sergio Goes de Paula. Rio de Janeiro: Editora Zahar, 2008.

CANOTILHO, José Joaquim Gomes; MOREIRA, Vital. Constituição da República Portuguesa Anotada. 4 ed. Coimbra: Coimbra Editora, 2007.

CARDIN, Valéria Silva Galdino Cardin; SILVA, Flávia Francielle da. Dos Direitos Culturais e Dos Direitos Humanos: da estigmatização do refugiado à construção do diálogo intercultural. Revista Brasileira de Direito Internacional. v. 2. n. 2. p. 78-99. Disponível 
em: <http://indexlaw.org/index.php/direitointernacional/article/view/1649/pdf >. Acesso em: 30 abr. 2017.

CARTA CAPITAL. "Sai do meu país!": agressão a refugiado expõe a xenofobia no Brasil. 2017. Disponível em: <https://www.cartacapital.com.br/politica/saia-do-meu-pais-agressao-arefugiado-no-rio-expoe-a-xenofobia-no-brasil>. Acesso em: 09 ago. 2017.

CASTRO, Celso A. Pinheiro de. Sociologia do Direito. 6 ed. São Paulo: Atlas, 1999

CHIRIBOGA, Oswaldo Ruiz. O direito à identidade cultural dos povos indígenas e das minorias nacionais: um olhar a partir do Sistema Interamericano. SUR - Revista Internacional de Direitos Humanos. São Paulo, n. 5, ano 3, 2006.

DIOGO, Helder Ramiro Sobral. Multiculturalismo: identidade e territorialidade na comunidade portuguesa de Lyon (França). Tese (Doutorado em Geografia Humana). Faculdade de Letras da Universidade do Porto. Porto, 2011.

DOLINGER, Jacob. Direito internacional privado: parte geral. 9 ed. atualizada. Rio de Janeiro: Renovar:2008.

EL PAÍS. Imigração e xenofobia. 2015. Disponível em: <https://brasil.elpais.com/brasil/2015/09/09/opinion/1441811691_233922.html>. Acesso em: 10 ago. 2017.

FONSECA, Fúlvio Eduardo; et. al. Diversidade Cultural e a Integração de Refugiados. 2011. Disponível em: <http://www.sinus.org.br/2011/press/downloads/sochum.pdf>. Acesso em: 09 ago. 2017,

FONTES, André R. C. O estrangeiro, o inimigo e o direito penal. CUNHA, Ricarlos Almagro Vitoriano (org.). Filosofia \& direito - ética, hermenêutica e jurisdição. Vitória: Seção Judiciaria do Espirito Santo, 2014.

HABERMAS, Jürgen. Direito democracia: entre facticidade e validade. Rio de Janeiro: Tempo Brasileiro, 2003.

HALL, Stuart. Da diáspora: Identidades e mediações culturais. Belo Horizonte: UFMG, 2003.

LOPES, Cristiane Maria Sbalquiero. Direito de Imigração: o Estatuto do Estrangeiro em uma perspectiva de Direitos Humanos. Porto Alegre: Núria Fabris, 2009.

LOPES, Ana Maria D’Ávila. Da coexistência à convivência com o outro: entre o multiculturalismo e a interculturalidade. Rev. Inter. Mob. Hum. ano XX, n. 38, p. 67-81 (2012). Disponível em: <csem.org.br/remhu/index.php/remhu/article/download/301/276>. Acesso em: 10 ago. 2017.

MARINUCCI, Roberto; MILESI, Rosita. Migrações Internacionais Contemporâneas. 2011. Disponível em: < http://www.ufjf.br/pur/files/2011/04/MIGRA\%C3\%87\%C3\%83ONO-MUNDO.pdf >. Acesso em: 09 ago. 2017. 
MELO, Luiz Renato de Souza; CARDOSO, Luciana Duarte. O DIREITO A TER DIREITOS: Os refugiados haitianos no Brasil. Revista de Direito Fibralex. n. 01. v. 01. Belém, 2016. Disponível em: <http://periodicos.fibrapara.edu.br/index.php/fibralex/article/view/37>. Acesso em: 06 nov. 2016.

MIRANDA, Jorge. Notas sobre cultura, Constituição e direitos culturais. In: O Direito. Lisboa: Universidade de Lisboa, 2006. Disponível em: <www.fd.ul.pt/Portals/0/Docs/Institutos/ICJ/LusCommune/MirandaJorge.pdf>. Acesso em: 03 set. 2016.

OLIVEIRA, Eliane de; SOUZA, Maria Luiza de. Multiculturalismo, diversidade cultural e direito coletivo na ordem contemporânea. Cadernos da Escola de Direito e Relações Internacionais. v. 3. n. 16 (2011). Disponível em: <http://revistas.unibrasil.com.br/ cadernosdireito/index.php/direito/article/view/776>. Acesso em: 11 ago. 2017.Eliane de Oliveira1 Maria Luiza de Souza

ORGANIZAÇÃO DA UNIDADE AFRICANA. Convenção da Organização da Unidade Africana (OUA). Disponível em: <http://www.dhnet.org.br/direitos/sip/africa/oua.htm\#pp2>. Acesso em: 24 mai 2017.

ORGANIZAÇÃO DAS NAÇÕES UNIDAS PARA A EDUCAÇÃO, A CIÊNCIA E A CULTURA (ONU). Convenção Relativa ao Estatuto dos Refugiados. Genebra: ACNUR, 1951. Disponível em: <http://www.acnur.org/t3/fileadmin/Documentos/portugues/BDL/ Convencao_relativa_ao_Estatuto_dos_Refugiados.pdf?view=1>. Acesso em: 31 jul. 2016.

\section{Convenção sobre a Proteção e Promoção da Diversidade das Expressões}

Culturais. 2005. Disponível em: <http://www.cultura.gov.br/politicas5//asset_publisher/WORBGxCla6bB/content/convencao-sobre-a-protecao-e-promocao-da-diver sidade-das-expressoes-culturais/10913>. Acesso em: 01 ago. 2016.

Programa das Nações Unidas para o Desenvolvimento (PNUD). Relatório sobre o Desenvolvimento Humano: Liberdade cultural num mundo diversificado. Lisboa, Portugal, 2004. Trad. José Freitas e Silva. Disponível em: <http://www.hdr.undp.org/en/media/hdr04_po_chapter_2.pdf>. Acesso em: 03 set. 2016.

Protocolo relativo ao Estatuto dos Refugiados de 1967. Genebra: ACNUR, 1967. Disponível em: <http://www.acnur.org/fileadmin/scripts/doc.php?file=fileadmin/Docume ntos/portugues/BD_Legal/Instrumentos_Internacionais/Protocolo_de_1967>. Acesso em: 31 jul. 2016.

. Declaração de Cartagena. Cartagena: ACNUR, 1984. Disponível em: <http://www.acnur.org/t3/fileadmin/Documentos/portugues/BD_Legal/Instrumentos_Internac ionais/Declaracao_de_Cartagena.pdf?view=1>. Acesso em: 01 ago. 2016.

Manual de procedimentos e critérios a aplicar para determinar o estatuto de refugiado: de acordo com a Convenção de 1951 e o Protocolo de 1967 relativos ao estatuto dos refugiados. Disponível em: <http://www.acnur.org/fileadmin/D 
ocumentos/portugues/Publicacoes/2013/Manual_de_procedimentos_e_criterios_para_a_deter minacao_da_condicao_de_refugiado.pdf?view=1>. Acesso em: 01 ago. 2016.

PAMPLONA, Danielle Anne; PIOVESAN, Flávia. O Instituto do Refúgio no Brasil: práticas recentes. In: Revista de Direitos Fundamentais e Democracia. v. 17, n. 17, 2015. Disponível em: http://revistaeletronicardfd.unibrasil.com.br/index.php/rdfd/article/view/629. Acesso em: 29 jul. 2016.

PATARRA, Neide Lopes. Migrações internacionais: teorias, políticas e movimentos sociais. Disponível em: 〈http://www.scielo.br/pdf/\%0D/ea/v20n57/a02v2057.pdf〉. Acesso em: 05 nov. 2016.

PIOVESAN, Flávia. Migrantes sob a perspectiva dos direitos humanos. In: Diversitas. n. 01 (2013). Disponível em: <http://www.revistas.usp.br/diversitas/article/view/58380/61381>. Acesso em: 06 set. 2016.

Igualdade, diferença e direitos humanos: perspectivas global e regional. In: LEITE, G.; SARLET, I. Direitos Fundamentais e Estados Constitucional: estudos em homenagem a j. j. gomes canotilho. São Paulo: RT/Coimbra, 2009.

Temas de Direitos Humanos. 4 ed. São Paulo: Saraiva. 2010.

SANTOS, Boaventura de Sousa (org). Reconhecer para libertar: os caminhos do cosmopolitismo multicultural. Porto: Anfrontamento. 2004.

; NUNES, J. A. Introdução: para ampliar o cânone do reconhecimento, da diferença e da igualdade. In: SOUSA SANTOS, B. (Org.). Reconhecer para libertar: os caminhos do cosmopolitismo multicultural. 2. ed. Rio de Janeiro: Civilização Brasileira, 2010.

SILVA, Vasco Pereira: A Cultura a que tenho Direto, Direitos Fundamentais e Cultura. Coimbra: Almedina, 2007.

SOARES, Mário Lúcio Quintão. A saga dos refugiados sob a égide do direito internacional, em tempo de globalização. In: Revista Duc In Altum: cadernos de Direito. v. 7, n. 13. Disponível em: < http://www.egov.ufsc.br:8080/portal/sites/default/files/448-1682-1-pb.pdf>. Acesso em: 05 abr. 2017.

SOUZA, João Francisco de. Atualidade de Paulo Freire: contribuição ao debate sobre a educação na diversidade cultural. Recife: Bagaço; Núcleo de Ensino, Pesquisa e Extensão em Educação de Jovens e Adultos e em Educação Popular da UFPE (NUPEP), 2001.

WINCKLER, Silvana. A condição jurídica atual dos imigrantes no cenário internacional à luz do pensamento da Hannah Arendt. AGUIAR, Odilio Alves (et al). Origens do Totalitarismo 50 anos depois. Rio de Janeiro: Relume Dumará; Fortaleza: Secretaria de Cultura de Desporto, 2001. 